\title{
The importance of permeability in granular filter design and control
}

\author{
F. Delgado-Ramos \\ University of Granada, Spain \\ D. Escudero-Merino \\ Technical University of Madrid, Spain \\ C. Olalla \\ Technical University of Madrid, Spain
}

ABSTRACT: Granular filters are required to perform two basic functions in embankment dams: (a) prevent the migration of base soil particles, and (b) allow drainage of seepage water. Traditionally, retention function (a) has been evaluated using Particle Size Distribution (PSD) and drainage function (b) using Permeability $\left(\mathrm{k}_{\mathrm{f}}\right)$, but usually permeability have been also correlated with PSD, so the permeability criterion have been expressed in terms of $D_{15 b}$ of the base soil and $D_{15 f}$ of the granular filter. Only few authors have used filter permeability for the assessment of retention function and there is no general agreement with them, but permeability should be a very important variable because it takes into account not only the whole PSD of the filter, (instead of just several representative diameters), but also other important characteristic such as compaction, porosity, density and particle shape. Based on a literature review and research experience at the University of Granada, this paper analyses the importance of filter permeability in the design and control of granular filters in embankment dams, even with dispersive base soils.

\section{INTRODUCTION}

Granular filters are used to prevent movement of base soil particles from or between various zones of embankment dams, avoiding the progression of internal erosion. The reliability of well-designed and constructed filters is so high that Sherard \& Dunnigan (1985) affirm that: "by providing conservative downstream filters, we can quit worrying about possible concentrated leaks through the core".

No dam designed in accordance with modern filtering requirements has suffered a severe failure incident (Fry et al. 1997), and it is known that in several dams which suffered the initiation of internal erosion, filters were able to stop the process even though they did not satisfy current design criteria (Foster \& Fell 2001), however, it is also true that, at least in laboratory tests, some filters that were designed using these rules have failed, specially if the base soil is dispersive (Vakili et al. 2015).

Traditionally, retention function has been assessed using Particle Size Distribution (PSD), and drainage function using Permeability (k), but usually permeability have been also correlated with PSD, so the drainage criterion have been expressed in terms of D15b of the base soil and D15f of the granular filter. Only few authors have used filter permeability for the assessment of retention function and there is no general agreement with them, but permeability should be a very important variable because it takes into account not only the whole PSD of the filter, (instead of just several representative diameters), but also other important characteristic such as compaction, porosity, density and particle shape.

Based on a literature review and laboratory test performed at the University of Granada, this paper analyses the importance of filter permeability in the design and control of granular filters in embankment dams, even with dispersive base soils.

The notation used in this paper is described in the following examples: $\mathrm{D}_{\mathrm{Xf}}=$ particle size of the filter material for which $\mathrm{X} \%$ by weight is finer, (in millimetres); $\mathrm{D}_{\mathrm{Xb}}=$ particle size of the base material for which $\mathrm{X} \%$ by weight is finer, (in millimetres); PP0.075B = percentage of base soil weight finer than $0.075 \mathrm{~mm}$; $\mathrm{kf}=$ filter permeability, (in centimetres per second).

\section{SHORT REVIEW OF CURRENT CRITERIA}

There are basically three groups of granular filter retention criteria: i) retention criteria based on the PSD of the filter, ii) retention criteria based on the constriction size distribution (CSD) of the filter, and iii) retention criteria based on the permeability of the filter.

Within the first group, the most widely accepted retention criterion was proposed by Sherard \& Dunnigan (1989). The authors set their criteria based on 
$\mathrm{D}_{15 \mathrm{f}}$ and $\mathrm{D}_{85 \mathrm{~b}}$, with different rules depending on the classification of the base soil according to its fines content. These criteria do not differentiate between dispersive and non-dispersive base soils. A general overview of well-known and widely used PSD-filter retention criteria is given by several authors such as ICOLD bol. 99 (1994); Honjo \& Veneciano (1989), Foster \& Fell, (1999); Delgado (2000); Foster \& Fell (2001) and Locke (2001). Some interesting advances have also been presented by authors such as Lone et al. (2005), for graded cohesionless bases, and Babu \& Srivastava (2007), trying to present an analytical criteria (see also discussion by Delgado \& Poyatos 2008). Possibly, one of the most interesting research works is the one performed at the University of New South Wales, (Australia), by Foster \& Fell (1999). They analysed a large number of data from different sources and those obtained from an extended program of laboratory tests using NEF (No Erosion Filter) and CEF (Continuing-Erosion Filter) tests and propose an improved filter design criteria, including dispersive base soils. Locke \& Indraratna (2002) introduced the reduced PSD method. It was addressed to broadly graded soils, but not directly to dispersive soils. The conception of the reduced PSD method can be attributed to the self-filtration behaviour in base soils. Thus $\mathrm{D}_{85 \text { reduced }}$ became the new representative base size. Its determination is described in Locke \& Indraratna (2002). Very recently, Vakili et al. (2015) proposed a new retention criterion using the $\mathrm{D}_{15 \mathrm{f}}$ and the $\mathrm{D}_{85 \mathrm{~b}}$ for dispersive base soils.

Within the second group of retention criteria, based on the constriction size distribution (CSD), one of the most interesting methodology was proposed by Raut \& Indraratna (2008). They established two important changes in representative base size and filter size. The criterion was established as: $\mathrm{D}_{\mathrm{c} 35} / \mathrm{d}^{*}{ }_{85} \leq 1$; where $\mathrm{D}_{\mathrm{c} 35}$, defined as the controlling constriction size of the filter, relates to the largest base particle that can erode through a filter; and where $\mathrm{d}_{85}^{*}=\mathrm{d}_{85}$ of the modified (re-graded) base soil grading curve by neglecting the base particles larger than the self-filtering constriction size, $\mathrm{D}_{\mathrm{c} 95}$, (Raut \& Indraratna 2008). It is more realistic because it takes into account the effects of filter compaction. The main disadvantage of the CSD-retention criteria is that the CSD is not measured using ordinary laboratory test, being necessary to use the computational procedure detailed by Indraratna et al. (2007) and computer subroutines shown in Raut (2006).

Finally, within the third group of retention criteria, those based on the filter permeability, there are few authors, such as Vaugham \& Soares (1982), Delgado (2000), Vaughan and Bridle (2004) and Delgado et al (2006).

The present paper will be focus on this minority group.

\section{CORRELATION BETWEEN FILTER PSD AND PERMEABILITY}

To compare the reliability of filter retention criteria that are based on the PSD of the filter with the reliability of filter retention criteria that are based on the permeability of the filter, it is necessary to explain clearly the correlation between these two variables.

Permeability of a granular filter mainly depends on its PSD, shape of the particles, and degree of compaction. Therefore, no one should use an equation that correlates PSD and $\mathrm{k}_{\mathrm{f}}$ without taking into account the other two variables: shape of the particles and degree of compaction.

For example, many authors use the correlation proposed by Sherard et al. (1984) showed in equation 1, but few of them notice that Sherard et al. (1984) showed that this coefficient 0.35 varies between 0.20 for highly compacted filters to 0.6 for less compacted filters.

$\mathrm{k}_{\mathrm{f}}=0.35\left(\mathrm{D}_{15 \mathrm{f}}\right)^{2}$

At the University of Granada we have measure the permeability of granular filters with angular particles and linear PSD, which are compacted with a surcharge during different times of vibration.

The correlation between the $\mathrm{D}_{15 \mathrm{f}}$ and the $\mathrm{K}_{\mathrm{f}}$ depending on the time of vibration are expressed in the following equations (Delgado, 2000):

$\begin{array}{ll}\mathrm{T} v=0 \mathrm{~s} & \mathrm{k}_{\mathrm{f}}=0.349\left(\mathrm{D}_{15 \mathrm{f}}\right)^{1.388} \\ \mathrm{~T} v=15 \mathrm{~s} & \mathrm{k}_{\mathrm{f}}=0.179\left(\mathrm{D}_{15 \mathrm{f}}\right)^{2} \\ \mathrm{~T} v=60 \mathrm{~s} & \mathrm{k}_{\mathrm{f}}=0.118\left(\mathrm{D}_{15 \mathrm{f}}\right)^{2} \\ \mathrm{Tv}=120 \mathrm{~s} & \mathrm{k}_{\mathrm{f}}=0.0808\left(\mathrm{D}_{15 \mathrm{f}}\right)^{2}\end{array}$

where Tv $=$ Compaction time $(\mathrm{s})$; $\mathrm{k}_{\mathrm{f}}=$ permeability coefficient of the filter $(\mathrm{cm} / \mathrm{s})$; and $D_{15 f}=$ size of filter material of which $15 \%$ of the material passes (mm).

The average relative density obtained for $\mathrm{Tv}=0$ was $63.2 \%$, for $\mathrm{Tv}=60$ was $78.5 \%$ and for $\mathrm{Tv}=120$ was $85.2 \%$.

The correlation obtained by Sherard et al. (1984) for less compacted filters, is similar to our correlation for 0 second of vibration (Ec. 2). The correlation obtained by Sherard et al. (1984) for highly compacted filters, is similar to our correlation for 15 second of vibration (Ec. 3). The famous correlation obtained by Sherard et al (1984) for averaged compacted filters, (Ec. 1) is between our equation 2 and equation 3 , but gives very much higher permeability than our correlation for 60 second of vibration (Ec. 4 ), that was considered the standard. 


\section{LABORATORY TEST RESULTS INCLUDING DISPERSIVE SOILS}

Usually the study of stability of base-filter systems involves direct experimentation through laboratory tests. The most well-known of these tests is the No Erosion Filter Test (NEF test) proposed by Sherard \& Dunnigan (1989).

This NEF test has been used at the University of Granada. The method is described in detail in Delgado \& Locke (2000) and some results have been published in Delgado (2000), Delgado et al. (2006), and Delgado-Ramos et al. (2012).

In this test the filter material is compacted inside a perspex cylinder, and a $2.54 \mathrm{~cm}$ thick layer of base soil is compacted above this filter. The base soil is perforated with a $1 \mathrm{~mm}$ diameter hole. The remainder of the cylinder is filled with gravel to still the water flow and the apparatus lid is sealed. Water is introduced under $392.28 \mathrm{kPa}$ of pressure $\left(4 \mathrm{~kg} / \mathrm{cm}^{2}\right)$ to force a flow through the pinhole.

Those tests performed under the same conditions as described by Sherard \& Dunnigan (1989) are denoted as "STANDARD". In addition, to best determine the effect of several influencing variables, some tests have several variations: filter compaction, base soil moisture water content, water pressure, and test duration.

During every NEF test, flow rate and turbidity are measured, and at the end of the test the pinhole of the base soil is observed. According to Sherard \& Dunningan (1989), the NEF test is considered "success" if there is no visible erosion in the pinhole, and "failure" if the pinhole has been eroded. Finally, the result is considered "intermediate" if there is slight erosion but the flow is quickly stabilised and water becomes clear.

A "boundary filter" can be selected for each base soil as the coarsest filter that gets no erosion at the pinhole. The NEF test is very sensitive: the boundary between "success" and "failure" is usually detected over a variation of $0.1 \mathrm{~mm}$ in the $\mathrm{D}_{15 \mathrm{f}}$. In average, to obtain the "boundary filter" for each base soil, 3 to $6 \mathrm{NEF}$ test are necessary.

In our investigation the filter material used in the tests was obtained from "El Portillo" dam (in the South of Spain). After washing on the $0.075 \mathrm{~mm}$ sieve it was split into distinct size fractions and reblended to obtain certain linear particle size distributions, defined by the $D_{15 f}$ and $D_{100 f}$ sizes. The Base material represents a good spread over the two classifications of soil groups 1 and 2 proposed by Sherard \& Dunnigan (1989) (this classification appears in Table 1). All the base soils tested were non dispersive.
Table 1. Classification of base soils (Sherard \& Dunnigan 1989).

\begin{tabular}{ll}
\hline Base soil group & Fines content of base soil: $\%$ \\
\hline Group 1 & $\geq 85$ \\
\hline Group 2 & 40 to 85 \\
\hline Group 3 & $\leq 15$ \\
\hline Group 4 & 15 to 40 \\
\hline
\end{tabular}

With these materials, 180 Standard NEF tests were done following the same specifications proposed by Sherard \& Dunnigan (1985), but also 113 tests modifying filter compaction energy, 21 tests mixing additives in the base soil, 27 tests reducing water pressure, 46 tests modifying base soil water content, and 23 more tests with several modifications.

The UGR-NEF tests database were completed with results from other researchers collected by Foster \& Fell (1999), as shown in Delgado et al. (2006).

Finally, for the present study, this database has been updated with results from Vakili \& Selamat (2014) and Vakili et al. (2015). These researchers reported $46 \mathrm{NEF}$ tests with dispersive soils.

Table 2 provides a listing of the adapted data used in the present study, (only containing base soil groups $1 \& 2$ ), giving basic information on test methods, source authors and the specific number of available data points for each category.

The only authors that extensively have tested dispersive base soils are Vakili \& Selamat (2014) and Vakili et al. (2015), therefore it is interesting to analyse here their results. They employed twenty-one different samples of base soils, whose properties are given in Table 3 , and thirteen different filters, whose properties are given in Table 4. Combining these materials were carried out $46 \mathrm{NEF}$ tests to directly determine the successful filter boundary. They compacted the filters by vibration and tamping to a relative density of $75 \%$.

Table 2. Data sources and filter test methods used in the analysis (only soil groups $1 \& 2$ ).

\begin{tabular}{lll}
\hline Test type & Source $^{* *}$ & $\#$ \\
\hline \multirow{2}{*}{$\begin{array}{l}\text { Conventional } \\
\text { base/filter tests }\end{array}$} & Sherard et al. & 20 \\
\cline { 2 - 3 } $\begin{array}{l}\text { Base suspension } \\
\text { tests }\end{array}$ & USBR & 4 \\
\cline { 2 - 3 } & Sherard et al. & 68 \\
\cline { 2 - 3 } & US Corps of Engineers & 1 \\
\cline { 2 - 3 } Preformed slot tests & Sherard et al. & 5 \\
\cline { 2 - 3 } & $\begin{array}{l}\text { Water Conservation and Ir- } \\
\text { rigation Commission }\end{array}$ & 26 \\
\hline \multirow{3}{*}{$\begin{array}{l}\text { No erosion filter } \\
\text { tests }\end{array}$} & Sherard et al. & 105 \\
\cline { 2 - 3 } & Foster \& Fell & 47 \\
\cline { 2 - 3 } & Delgado (UGR NEF tests) & 340 \\
\cline { 2 - 3 } & $\begin{array}{l}\text { Vakili \& Selamat and } \\
\text { Vakili et al. }\end{array}$ & 46 \\
\hline Total size of data set for filter stability analysis & 731 \\
\hline \multirow{2}{*}{$\begin{array}{l}\text { Note: } \\
\text { in table } 3 \text { For the lack of space, the list of references contained }\end{array}$} &
\end{tabular}


Table 3. Properties of Malaysian samples for base soils (Vakili et al. 2015).

\begin{tabular}{|c|c|c|c|c|c|}
\hline $\begin{array}{l}\text { Sample } \\
\text { no. }\end{array}$ & $\mathrm{d}_{85} \mathrm{~mm}$ & $\begin{array}{l}\text { Fine con- } \\
\text { tent: } \%\end{array}$ & PI: \% & D:\% & $\begin{array}{l}\text { class dis- } \\
\text { persion }\end{array}$ \\
\hline $1-\mathrm{s} 1$ & 0,03 & 91 & 16 & 93 & HD \\
\hline $1-s 2$ & 0,065 & 88 & 17 & 51 & HD \\
\hline $1-\mathrm{s} 3$ & 0,038 & 92 & 24 & 61 & HD \\
\hline $1-\mathrm{s} 4$ & 0,02 & 96 & 35 & 82 & HD \\
\hline $1-\mathrm{s} 5$ & 0,015 & 100 & 31 & 45 & MD \\
\hline $1-s 6$ & 0,062 & 86 & 13 & 32 & $\mathrm{MD}$ \\
\hline $1-s 7$ & 0,055 & 90 & 8 & 69 & HD \\
\hline $1-s 8$ & 0,05 & 92 & 12 & 41 & MD \\
\hline $1-\mathrm{s} 9$ & 0,044 & 88 & 17 & 82 & HD \\
\hline $1-\mathrm{s} 10$ & 0,06 & 88 & 24 & 75 & HD \\
\hline 2-s11 & 0,2 & 83 & 16 & 65 & HD \\
\hline 2-s12 & 0,1 & 82 & 20 & 74 & HD \\
\hline 2-s13 & 0,3 & 76 & 15 & 32 & $\mathrm{MD}$ \\
\hline 2-s14 & 0,15 & 78 & 25 & 15 & ND \\
\hline 2-s15 & 0,15 & 75 & 16 & 50 & HD \\
\hline $2-s 16$ & 0,09 & 83 & 31 & 43 & MD \\
\hline 2-s17 & 0,091 & 83 & 17 & 81 & HD \\
\hline 2-s18 & 0,13 & 71 & 11 & 89 & HD \\
\hline 2-s19 & 0,18 & 80 & 18 & 56 & HD \\
\hline $2-s 20$ & 0,09 & 82 & 17 & 37 & MD \\
\hline $2-s 21$ & 0,023 & 75 & 13 & 9 & ND \\
\hline
\end{tabular}

Note: PI; plasticity index; D: percent dispersion; HD: highly dispersive; MD: moderately dispersive; ND: non dispersive. Soils with $\mathrm{D} \geq 50 \%$ are considered highly dispersive, soils with between 30 and $50 \%$ dispersion are moderately dispersive, and soils with $\mathrm{D} \leq 15 \%$ are nondispersive.

It is very important to compare the correlation between filter PSD and permeability obtained by Vakili \& Selamat (2014), with equations 1 to 5. As can be seen in Figure 1, the filters tested by Vakili \& Selamat (2014) and Vakili et al. (2015), have very high permeability, even higher that the permeability that we have obtained without compaction of the filter.

Table 4. Properties of filter materials (Vakili \& Selamat 2014).

\begin{tabular}{llllll}
\hline $\begin{array}{l}\text { Filter } \\
\text { no. }\end{array}$ & $\begin{array}{l}\mathrm{D}_{5 \mathrm{f}} \\
\mathrm{mm}\end{array}$ & $\begin{array}{l}\mathrm{D}_{15 \mathrm{f}} \\
\mathrm{mm}\end{array}$ & $\begin{array}{l}\mathrm{D}_{100 \mathrm{f}} \\
\mathrm{mm}\end{array}$ & $\mathrm{C}_{\mathrm{u}}$ & $\begin{array}{l}\mathrm{k}_{\mathrm{f}} \\
\mathrm{cm} / \mathrm{s}\end{array}$ \\
\hline $\mathrm{F}_{1}$ & 0.55 & 0.85 & 20.00 & 5.3 & $486.9 \times 10^{-3}$ \\
\hline $\mathrm{F}_{2}$ & 0.52 & 0.80 & 20.00 & 5.38 & $422.4 \times 10^{-3}$ \\
\hline $\mathrm{F}_{3}$ & 0.51 & 0.75 & 20.00 & 5.16 & $342.9 \times 10^{-3}$ \\
\hline $\mathrm{F}_{4}$ & 0.50 & 0.70 & 20.00 & 5.00 & $303.9 \times 10^{-3}$ \\
\hline $\mathrm{F}_{5}$ & 0.47 & 0.65 & 20.00 & 4.91 & $277.5 \times 10^{-3}$ \\
\hline $\mathrm{F}_{6}$ & 0.425 & 0.60 & 10.00 & 4.00 & $247.0 \times 10^{-3}$ \\
\hline $\mathrm{F}_{7}$ & 0.38 & 0.55 & 10.00 & 4.02 & $123.0 \times 10^{-3}$ \\
\hline $\mathrm{F}_{8}$ & 0.35 & 0.50 & 10.00 & 4.12 & $101.7 \times 10^{-3}$ \\
\hline $\mathrm{F}_{9}$ & 0.25 & 0.425 & 4.75 & 4.29 & $75.7 \times 10^{-3}$ \\
\hline $\mathrm{F}_{10}$ & 0.2 & 0.35 & 4.75 & 4.44 & $52.1 \times 10^{-3}$ \\
\hline $\mathrm{F}_{11}$ & 0.18 & 0.28 & 4.75 & 5.2 & $33.8 \times 10^{-3}$ \\
\hline $\mathrm{F}_{12}$ & 0.14 & 0.2 & 2.00 & 4.11 & $16.1 \times 10^{-3}$ \\
\hline $\mathrm{F}_{13}$ & 0.12 & 0.17 & 2.00 & 4.0 & $6.73 \times 10^{-3}$ \\
\hline $\mathrm{N}_{0}$ &
\end{tabular}

Note: $\mathrm{C}_{\mathrm{u}}=$ coefficient of uniformity of he filter.
In any case we have added these new results to our database. Figure 2 shows the results of the 348 NEF tests provided by external sources, 159 "standard" NEF tests from Delgado (2000), and the new 46 results with dispersive base soils obtained by Vakili \& Selamat (2014) and Vakili et al. (2015), all presented in the context of the well known and widely accepted soil group $1 \& 2$ filter design criteria by Sherard \& Dunnigan (1989).

As can be seen, the criterion of Sherard \& Dunningan (1989) is insufficient for dispersive soils. It is true that successes are within the criteria, but also many failures. Vakili \& Selamat (2014) reported that only $50 \%$ of the results are compatible compared with Sherard \& Dunnigan (1989) criteria. Statement that agrees with the observation made by Foster \& Fell (1999) that Sherard's criterion for soil group 1 corresponds to a probability of failure of about 0.5 to 0.55 and is therefore not always conservative. In addition to this, Foster \& Fell (2001) observed a possible decrease of the Sherard's erosion boundaries in case of dispersive base soils. But the criteria set by Foster \& Fell (2001) is only compatible in $72 \%$ of the results as reported Vakili \& Selamat (2014). Furthermore, these researchers also reported that their NEF test results were found to be only $61 \%$ compatible with Shourijeh \& Soroush (2009) criteria. For that reason, Vakili et al. (2015) have proposed new retention criteria based on the PSD of the filter and the PSD of the dispersive base soil.

But now it is necessary to compare these new results with the criteria proposed by Delgado et al. (2006). Figure 3 presents the relation between filter permeability $\mathrm{k}_{\mathrm{f}}$ and percentage of base soil passing the $0.075 \mathrm{~mm}$ sieve (P0.075B). As can be seen, even the NEF test result with dispersive soils obtained by Vakili \& Selamat (2014) and Vakili et al. (2015) are totally compatible with the boundary filter lower limit proposed by Delgado et al. (2006) criteria. 


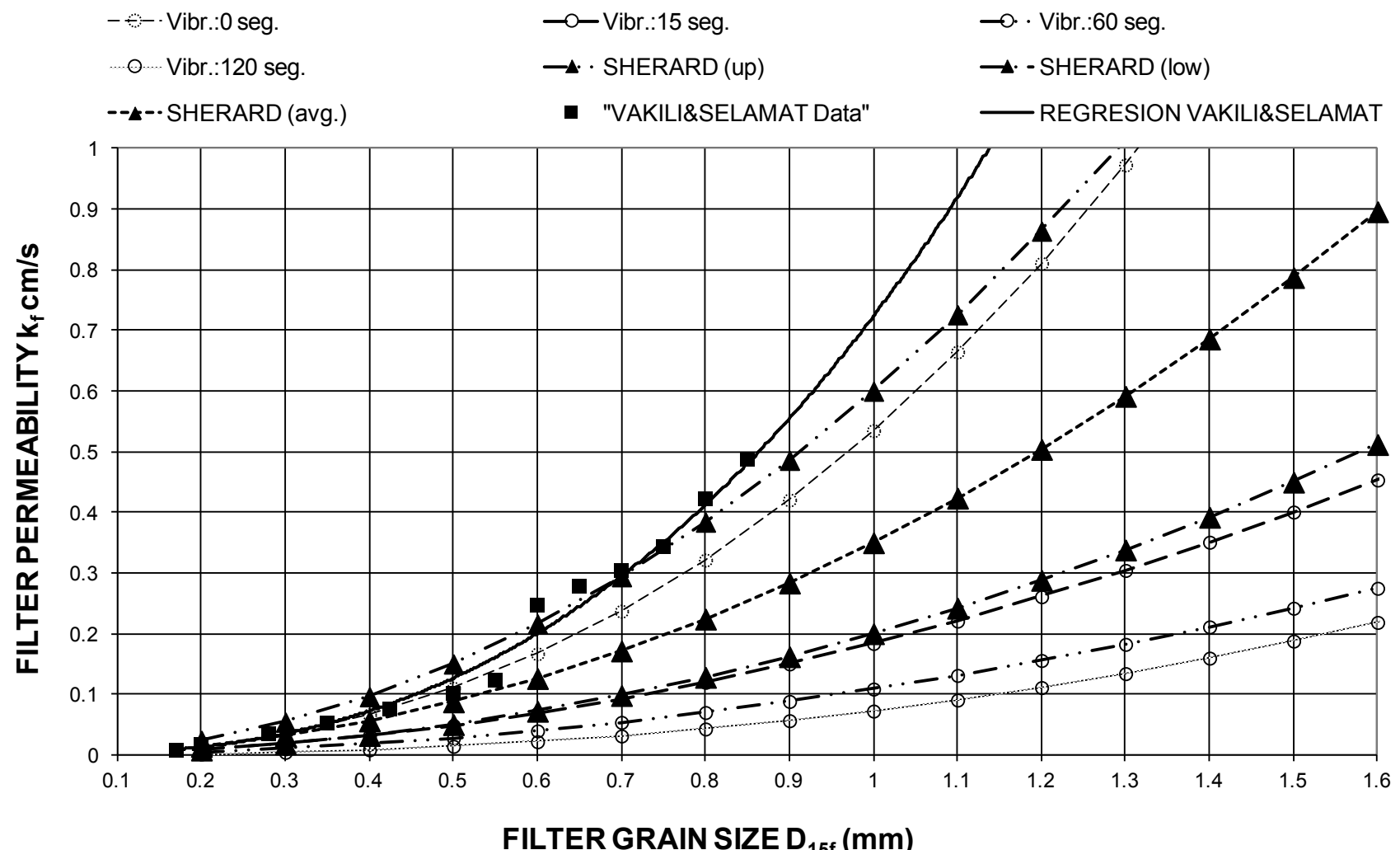

Figure 1. Relationship between grain size $\mathrm{D}_{15 \mathrm{~F}}$ and permeability $\mathrm{k}_{\mathrm{f}}$ of a filter soil with different times of compaction under vibration, from Delgado (2000), compared to Sherard et al. (1984) and Vakili \& Selamat (2014).

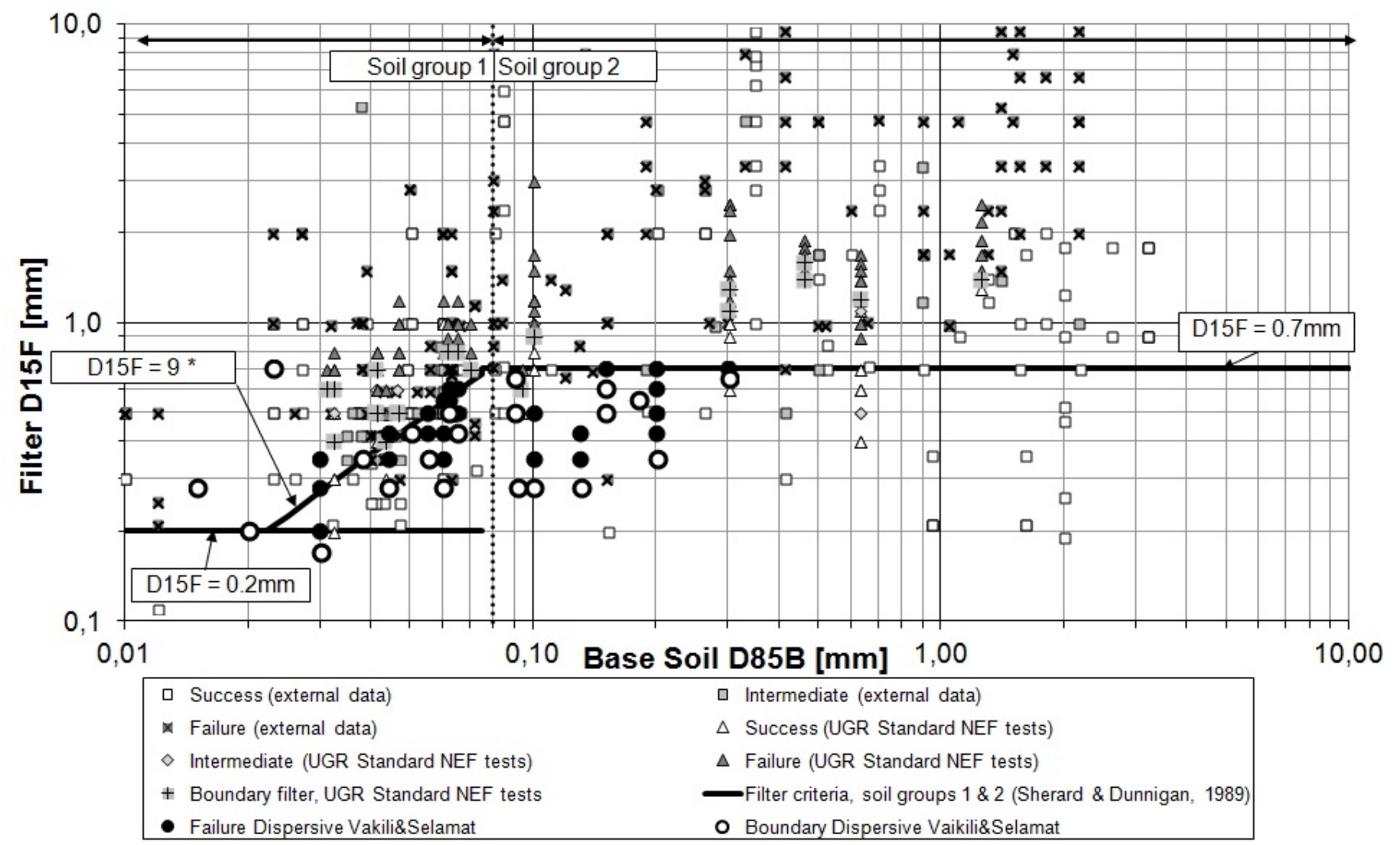

Figure 2. Relationship between $\mathrm{D}_{15 \mathrm{f}}$ and $\mathrm{d}_{85 \mathrm{~b}}$ for all external data, UGR standard NEF tests, Vakili \& Selamat (2014) and Vakili et al. (2015). 


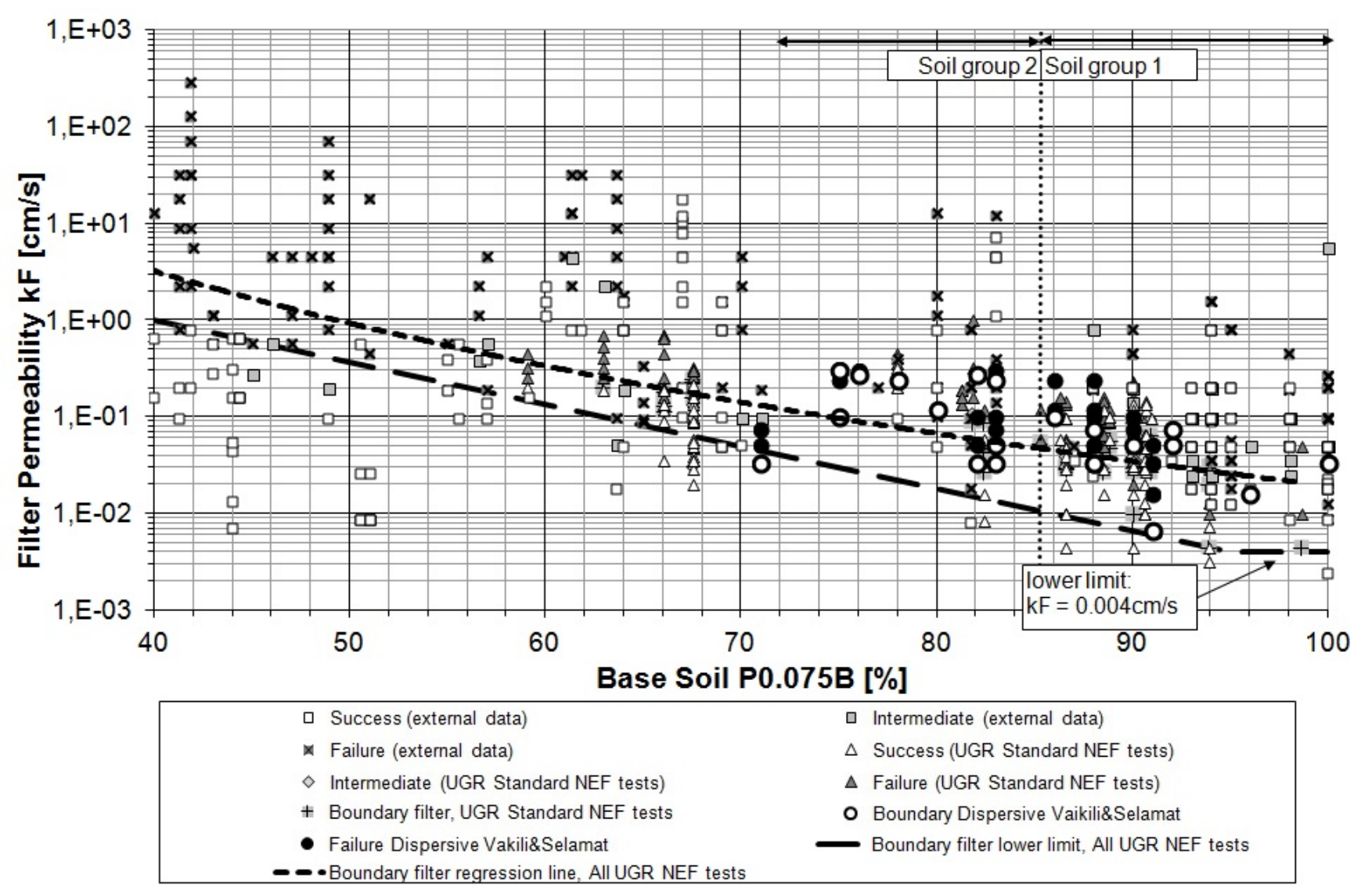

Figure 3 Relationship between $\mathrm{k}_{\mathrm{f}}$ and P0.075B for all external data and UGR NEF tests, Vakili \& Selamat (2014) and Vakili et al. (2015).

\section{CONCLUSIONS}

The results of the NEF test using dispersive base soils obtained by Vakili \& Selamat (2014) and Vakili et al. (2015) show that the traditional retention criteria based on the $D_{15 f}$ and the $D_{85 b}$ are not conservative enough for this kind of base soils, but before using the new criteria proposed by Vakili et al. (2015) for dispersive base soils, further analysis is needed in order to perform the same NEF test but with higher compaction of the filters, because the filter permeabilities that they have measured are very high compared to previous work of Sherard et al. (1984) and Delgado (2000).

Nevertheless, the retention criterion proposed by Delgado et al. (2006) using the permeability of the filter and the fines content of the base soil, has shown to be reliable even for the dispersive base soils tested by Vakili \& Selamat (2014) and Vakili et al. (2015).

Therefore, permeability of the filter is not only necessary for the assessment of the drainage function of a granular filter, but also for the retention function. But the permeability of the filter must be directly measured in a permeameter with the same conditions of compaction expected in the dam, and never estimated using simple equations obtained by other researchers without taking into account their compaction conditions. Filter permeability can be also measured in-situ, for example with the methodology proposed by Matsuo et al. (1953).

\section{REFERENCES:}

Babu, G. L. S., \& Srivastava, A. (2007). A procedure for the design of protective filters. Canadian Geotechnical Journal, 44(4), 490-495.

Delgado, F., \& Poyatos, J. M. (2008). Discussion of "A procedure for the design of protective filters" Appears in Canadian Geotechnical Journal, 44: 490-495. Canadian geotechnical journal, 45(3), 437-439.

Delgado Ramos, F. (2000). 'Laboratory simulation of the internal erosion phenomenon to determine the variables that influence the efficiency of filters for cohesive soils (Doctoral dissertation, $\mathrm{PhD}$ thesis, University of Granada, Granada, Spain (in Spanish)).

Delgado Ramos, F., \& Locke, M. (2000). Design of granular filters: Guidelines and recommendations for laboratory testing. Filters and Drainage in Geotechnical and Environmental Engineering, Geofilters, 115-122.

Delgado, F., Huber, N., Escuder, I. And De Membrillera, M. (2006). "Revised criteria for evaluating granular filters in earth and rockfill dams." In Transactions of the 22nd International Congress on Large Dams (ICOLD), Barcelona, Spain, 18- 23 June 2006. International Comission on Large Dams (ICOLD), Paris. Vol. 3, pp. 445 - 456

Delgado-Ramos, F., Poyatos, J. M., \& Osorio, F. (2012). Internal erosion of clayey soils protected by granular filters. $L a$ Houille Blanche, (4-5), 42-47. 
Foster, M., \& Fell, R. (2001). Assessing embankment dam filters that do not satisfy design criteria. Journal of Geotechnical and Geoenvironmental Engineering, 127(5), 398-407.

Foster, M., \& Fell, R. (2001). Assessing embankment dam filters that do not satisfy design criteria. Journal of Geotechnical and Geoenvironmental Engineering, 127(5), 398-407.

Fry, J.J., Brun, P., Lautrin, D., Albalat, C., Droux, J.M., Mercier, A., Riesterer, J.M., Thareau, L., Degoutte, G. (1997), Typologie de l'érosion interne et détection, XIX ICOLD, Q.73, R.47, Florence.

Honjo, Y., \& Veneziano, D. (1989). Improved filter criterion for cohesionless soils. Journal of Geotechnical Engineering, 115(1), 75-94.

ICOLD bol. 99 (1994): Embankment Dams: Granular Filters and Drains. Review and Recommendations. Paris: International Commission on Large Dams (ICOLD) (Bulletin / International Commission on Large Dams; 95).

Indraratna, B., Raut, A. K., \& Khabbaz, H. (2007). Constriction-based retention criterion for granular filter design. Journal of Geotechnical and Geoenvironmental Engineering, 133(3), 266-276.

Locke, M., \& Indraratna, B. (2002). Filtration of broadly graded soils: the reduced PSD method. Faculty of EngineeringPapers, 389.

Locke, M. R. (2001). Analytical and laboratory modelling of granular filters for embankment dams.

Lone, M. A., Hussain, B., \& Asawa, G. L. (2005). Filter design criteria for graded cohesionless bases. Journal of geotechnical and geoenvironmental engineering, 131(2), 251-259.

Matsuo, S., Houmachi, S. \& Akai, K. (1953). A field Determination of Permeability. Proc. 3rd International Conference on Soil Mechanics and Foundations Engineering. p.268.

Raut, A. K. (2006). Mathematical modelling of granular filters and constriction-based filter design criteria. University of Wollongong Thesis Collection, 44.

Raut, A. K., \& Indraratna, B. (2008). Further advancement in filtration criteria through constriction-based techniques. Journal of geotechnical and geoenvironmental engineering, 134(6), 883-887.

Sherard, J. L., \& Dunnigan, L. P. (1985, May). Filters and leakage control in embankment dams. In Seepage and leakage from dams and impoundments(pp. 1-30). ASCE.

Sherard, J. L., \& Dunnigan, L. P. (1989). Critical filters for impervious soils.Journal of Geotechnical Engineering, 115(7), 927-947.

Sherard, J. L., Dunnigan, L. P., \& Talbot, J. R. (1984). Filters for silts and clays. Journal of Geotechnical Engineering, 110(6), 701-718.

Tabatabaie Shourijeh, P., \& Soroush, A. (2009). Statistical study of no-erosion filter (NEF) test results. Proceedings of the Institution of Civil Engineers-Geotechnical Engineering, 162(3), 165-174.

Vakili, A. H., \& Selamat, M. R. B. (2014). An assessment of veracity of filter criteria for earth dams. Proceedings of the Institution of Civil Engineers-Geotechnical Engineering, 167(6), 574-584.

Vakili, A. H., Bin Selamat, M. R., \& Abdul Aziz, H. B. (2015). Filtration of Broadly Graded Cohesive Dispersive Base Soils. Journal of Geotechnical and Geoenvironmental Engineering, 141(5), 04015004.

Vaughan, P. R., \& Bridle, R. C. (2004). An update on perfect filters. Long-term Benefits and Performance of Dams (Hewlett H (ed.)). Thomas Telford, London, UK, 516-531.

Vaughan, P. R., \& Soares, H. F. (1982). Design of filters for clay cores of dams. Journal of Geotechnical and Geoenvironmental Engineering, 108(ASCE 16807). 